The Geneva Papers on Risk and Insurance, 19 (No. 70, January 1994), 70 - 84

\title{
Audit Fee Determination and Governance Structure: Empirical Evidence from UK Insurance Companies
}

\author{
by N. O'Sullivan* and S.R. Diacon**
}

\section{Introduction}

The purpose of this paper is to use the governance characteristics of insurance companies to obtain further insights into auditors' pricing decisions. Auditors are uniquely placed to assess the quality of corporate governance since the auditor's liability exposure suggests that its view of a company's governance quality is reflected in the price charged for the audit.

The quality of corporate governance is presently a matter of considerable concern in the United Kingdom. A key feature of the current debate is the perceived lack of confidence in corporate financial reporting [Committee on the Financial Aspects of Corporate Governance, 1992, p. 14]. An integral part of the financial reporting process is the statutory audit which provides independent verification of corporate disclosures. In recent years, however, the auditor's role in corporate governance has been questioned. The failure of a number of high profile companies, without prior auditor warning, has raised questions about audit quality. In some instances audit users have blamed auditors explicitly for not identifying impending corporate failure and have initiated litigation in an attempt to obtain recompense for their losses [Financial Times, 13th March, 1992, p. 7]. In such a hostile audit environment it is interesting to examine whether auditors are capable of identifying potentially troublesome audit assignments.

The study of United Kingdom insurance companies is particularly interesting because of the variety of governance issues available for analysis. We conduct an empirical examination of the effects of organisational form, class of business, board composition, and length of the auditor/client relationship on the audit fee paid by UK insurance companies. The data is drawn from a pooled cross-section/time series data base on one hundred and seventeen companies for the period 1984-91.

It is hoped that the present analysis will contribute to the existing literature in a number of ways:

(i) the insurance industry comprises or both stock and mutual companies which facilitates an analysis of the effect of organisational form on the auditor's pricing decision;

\footnotetext{
* Association of British Insurers Research Fellow, University of Notttingham.

** Director, University of Nottingham Insurance Centre, Nottingham.
} 
(ii) the use of data on the governance characteristics of audit clients adds a new dimension to our study. In particular, the current emphasis on the importance of board composition and the separation of the roles of chairman and chief executive suggests a need to examine the effects of these factors on the pricing of initial engagements and 'renewal' audit contracts;

(iii) apart from Low et al [1989] and Brinn et al [1992], existing research has examined samples across industries, thereby failing to test for industry-specific factors. Industryspecific models are also capable of evaluating the effect of a particular auditor's market share on its pricing decision and produce sharper insights than the crude 'big-six' distinction used in previous research;

(iv) studies of auditor litigation in the US indicate that auditors of finance and insurance companies face an increased likelihood of litigation [Palmrose, 1988 and St. Pierre and Anderson, 1984]. Recent instances of auditor litigation in the UK also support the suggestion that auditors of financial service companies are exposed to increased risk: for example the Guardian Royal Exchange Insurance Group announced recently that it intends to sue its former auditors in relation to audit and other services performed in the late 1980s [Financial Times, 4th January, 1993];

(v) by analyzing the audit fee over an eight year period, our study should provide some insight into the effects of continuity and auditor change on the audit pricing process.

The paper proceeds as follows: the next section discusses the auditor's role in corporate disclosure paying particular attention to the relationship between audit risk and corporate governance. Section three discusses the factors likely to affect audit pricing in the insurance industry. Section four describes the data. Section five introduces the model and discusses the results. Some conclusions and suggestions for future research are mentioned in section six.

\section{Audit risk and corporate governance}

The possibility of stakeholder litigation in the event of audit failure has prompted researchers to recognise the role of the courts in implementing audit contracts [Melumad and Thoman, 1990a and 1990b; Wallin 1992]. An important implication of the potential impact of legal liability on the auditor-client contracting process is an acceptance that, in order to obtain maximum benefit from the contract, the auditor is capable of evaluating the degree of risk presented in each audit engagement.

In the context of this paper, audit risk arises not just because of the non-zero probabilities of a negligent audit (as discussed in Kaplan, 1985 and Thornton and Moore, 1993) but also from stakeholder discovery of such negligence. Negligent auditing exposes auditors to two types of cost : first stakeholders who rely on an inaccurate audit report may initiate litigation against the auditor in order to recover any resulting losses, thereby exposing the auditor to direct financial loss (see O'Sullivan, 1993). Secondly, allegations of negligence affect adversely the auditor's reputation thus impairing its future earning potential (which is explored further in Diacon and O'Sullivan, 1993).

In the UK, the Insurance Companies Act 1982 and the Companies Act 1985 outline the reporting responsibilities of the directors and auditors of insurance companies. The auditors need to ascertain whether the directors' accounts have been properly prepared in accordance with the terms of the legislation and whether the accompanying directors' report is 
consistent with the financial statements. Therefore, the probability of the auditor being exposed to stakeholder litigation is greatly influenced by the care with which the client prepares the initial financial statements. In addition, stakeholder litigation is unlikely to ensue without the occurrencc of an event which leads to an investigation into the quality of a company's financial statements (such as auditor change, insolvency, new capital issue, acquisition, or some other form of corporate rcstructuring).

Corporate governance is the system by which companies arc dirccted and controlled, and is primarily concerned with the degree of control exerted over the behaviour of company management. Walsh and Seward [1990] explain that such control can be exerted by both external mechanisms (such as the market for corporate control, and the size and concentration of shareholdcrs) and internal mechanisms such as the Board of Directors (particularly non-executives), and an independent company Chairnıan. We are interested in the extent to which the internal and external governance of UK insurance companies influences auditor behaviour, and is reflected in the audit fee.

The impact of corporate governance on audit risk is unclear. Companies with strong internal governance should produce more reliable financial statements with a consequent reduction in the problems for auditors. However, with strong external governance, the risk of discovery of any audit error (arising from the failure to detect mistakes in the financial statements) is likely to be greater.

The existence of the (external) market for corporate control and its ability to discipline inefficient managers creates confusion as to whether the management of stock companies are more or less likely to produce unreliable financial statements. On the one hand, managers who may be fearful of being replaced are encouraged to present the company's financial position as favourably as possible [De Angelo, 1988], particularly since the threat of managerial displacement appears to be negatively related to corporate performance [Weisbach, 1988]. However, the possibility of takeover, which increases the likelihood of discovery of management mis-representation, suggests that exposure to the capital market may act as a deterrent against financial statement manipulation.

The Board of Directors is the most important internal monitoring device for UK companies (which lack the two-tier board structure common in some other European countries). The Committee on the Financial Aspects of Corporate Governance [1992] placed great emphasis on the board's role in improving the quality of UK corporate governance, stressing the importance of some non-executive representation. There is reason to believe that boards containing a significant proportion of non-executive directors are associated with better governance quality [Brickley and James, 1987], and have a positive effect on shareholder wealth [Roscnstein and Wyatt, 1990]. In addition, individual non-executive directors are likely to be selected because of their acknowledged managerial ability [Kaplan and Reishus, 1990].

Even though the existence of a separate Chairman and Chief Executive Officer has received very little academic attention, it is an issue which has recently become closely associated with governance quality. The Committee on the Financial Aspects of Corporate Governance [1992] made provision in its code of best practice that there "should be a clcarly accepted division of responsibilities at the head of the company, which will ensure a balance of power and authority, such that no individual has unfettered powers of decision" 
[p. 6]. The recent problems encountered by the Maxwell group of companies highlighted the dangers of uniting the roles of Chief Executive and Chairman, particularly because other members of the Board may be excluded from the decision-making process.

\section{Audit pricing and corporate governance in the UK insurance industry}

The existence of possible auditor error, which may expose the auditor to substantial liabilities, has a number of implications for the pricing of audit contracts. Risk-averse auditors will control the risk of audit error by taking costly care in the performance of their duties, and by reducing the probability that any audit error will be discovered. This care is likely to have implications for the level of audit fee. In Diacon and O'Sullivan [1993] we show that the discovery probability is also determined by the pricing of subsequent 'renewal' audit contracts, since discovery is more likely if the contract is lost to a competitor.

The effect of a company's governance structure on the level of audit fee charged is ambiguous, and depends on the nature of governance and on whether or not the audit contract is a new engagement. In general, strong internal governance (associated with lower levels of audit risk) should result in smaller audit fees - particularly for new engagements. However insurers with strong external governance (which increases the discovery risk) may have higher or even lower 'renewal' fees since auditors may want to reduce subsequent audit fees in order to control the risk of discovery of previous audit error.

Other research highlights consistently the importance of client size and complexity on the auditor's pricing decision [Simunic, 1980; Simon, 1985; Firth, 1985; Low et al, 1989 and Brinn et al, 1992]. Size is typically represented by the amount of assets and/or annual turnover. The degree of complexity is commonly measured in terms of the auditee's degree of diversification as well as the number and location of subsidiaries. In addition, auditor size [Palmrose, 1986], length of auditor-client relationship [Turpen, 1990; Ettredge and Greenberg, 1990], audit market competition [Maher et al, 1992], and the auditor's incentive to expend effort in the performance of the audit contract [Antle, 1982; Baiman et al, 1987] have all been identified as important determinants of the audit price.

The particular variables which are hypothesised to influence audit pricing in the insurance industry include organisational form, type of business, corporate status, and other governance variables discussed in the preceeding section (such as board composition and the separation of CEO and Chairman).

\section{Organisational form}

The co-existence of both stock and mutual companies in the UK insurance market makes the insurance industry an attractive laboratory for examining corporate governance issues. Previous work has addressed the implications of organisational form on acceptable levels of risk [Lamm-Tennant and Starks, 1993]; executive compensation [Mayers and Smith, 1992]; the use of differential contracting [Smith and Stutzer, 1990] and expense preference behaviour and other agency problems [Fields, 1988 and Fields and Tirtiroglu, 1991].

Mayers and Smith, 1992 observe that executive compensation is more responsive to corporate performance in stock insurance companies than in mutuals, suggesting an incentive for managers of proprietary companies to manipulate their disclosures. In addition, Lamm-Tennant and Starks [1993] report evidence that stock insurers operate in areas of greater risk than mutual insurers, which suggests a need for rigorous and more expensive 
auditing. O'Hara [1981] reports a similar finding when comparing mutual and stock Savings and Loans Associations. The absence of a capital market may result in more lacklustre and inefficient internal control mechanisms in mutual companies, increasing the probability of unintentional financial statement error. Of course, whether the financial statements are deliberately or unintentionally mis-stated, the probability of audit error detection is substantially less for mutual companies.

In the case of mutual insurance companies, the key issue is whether any alternative governance structures can compensate for the absence of a capital market discipline. In a parallel study on the banking industry, Brickley and James [1987] found that, in US states where takeovers were not allowed, outside directors served to reduce managerial consumption of perquisites. This suggests that the composition of the board of directors of mutual insurers might influence the auditor's perceptions of the risk involved.

\section{Type of business}

UK insurance companies can be divided into three types depending upon the type of business written. Specialist general insurers underwrite property and/or liability business only. Specialist long term insurers underwrite life and pensions business only. In addition, a number insurance groups write both general and long term business. Each type of insurer might present a different risk to the auditor.

St. Pierre and Anderson [1984] report that auditor litigation frequently arises from management manipulation of those items in the accounts which are difficult to measure precisely. The particular difficulties in compiling general insurance company revenue accounts and balance sheets are well recognised (for example see Diacon ed, 1991). Furthermore, in a recent article, Petroni [1992] finds evidence of under-reporting of potential liability in the property-liability insurance industry in the US. Of particular significance is her finding that the probability of such manipulation is negatively related to the company's financial position. The results of Petroni's research indicates potential liability problems in the audit of companies transacting general insurance business.

\section{Corporate status}

A significant proportion of companies operating in the UK insurance industry are either foreign companies or have subsidiaries in foreign countries. The threat of having to defend a negligence action in a non-UK court (particularly in the US) is likely to encourage the auditor to increase its fee.

\section{Data description and sources}

We obtained data on the audit fee and other financial characteristics of the largest 117 UK-registered insurance companies from annual Report and Accounts filed in the library of the University of Nottingham Insurance Centre. The data covers the eight years between 1984 and 1991 inclusive and relates to either the consolidated worldwide business of companies with UK headquarters or to the UK business of foreign companies. United Kingdom companies are required under various Companies Acts to publish their auditor's report and cite the audit fee paid.

Most of the information on the size/turnover of the leading UK audit firms was obtained from annual tables published by Accountancy Age. One advantage of concentrating our analysis on the insurance industry is that there are less than forty audit firms specialising in insurance company auditing. We were therefore able to gather data on the total turnover (fee income) and size ranking for all the audit firms involved. The data is summarised in Table 1. 
Table 1:

Description of dependent and independent variables : 1984-1991

\begin{tabular}{|c|c|c|c|c|c|}
\hline \multicolumn{2}{|l|}{ Variable } & Mean & $\begin{array}{l}\text { Stand. } \\
\text { Deviat. }\end{array}$ & Min. & Max. \\
\hline $\log$ Audit Fee & $(£ 000)$ & 4.045 & 1.252 & 0.765 & 7.625 \\
\hline $\log ($ General Premiums +1$)$ & $(£ \mathrm{~m})$ & 7.001 & 5.097 & 0 & 14.914 \\
\hline $\log ($ Life Premiums +1$)$ & $(£ \mathrm{~m})$ & 5.761 & 6.014 & 0 & 15.228 \\
\hline log Auditor Turnover & $(£ 000)$ & 11.550 & 1.518 & 4.555 & 13.009 \\
\hline Assets/Premiums & & 5.855 & 7.966 & 0.257 & 102.23 \\
\hline No. of Subsidiaries & & 5.832 & 9.949 & 0 & 63 \\
\hline$\%$ Non-Executive Directors & & 57.748 & 29.28 & 0 & 100 \\
\hline General Underwriting Ratio & & -10.05 & 28.31 & -392 & 95.24 \\
\hline Auditor Insurance Mkt Share & & 14.989 & 12.73 & 0.043 & 47.68 \\
\hline Mutual Dummy & & 0.230 & 0.421 & 0 & 1 \\
\hline Separate CEO/Chairman Dummy & & 0.863 & 0.344 & 0 & 1 \\
\hline Reinsurance Dummy & & 0.111 & 0.314 & 0 & 1 \\
\hline Subsidiary Dummy & & 0.662 & 0.473 & 0 & 1 \\
\hline Overseas Parent Dummy & & 0.413 & 0.243 & 0 & 1 \\
\hline US Subsidiary Dummy & & 0.128 & 0.335 & 0 & 1 \\
\hline London Auditor Dummy & & 0.754 & 0.431 & 0 & 1 \\
\hline UK HO Dummy & & 0.568 & 0.496 & 0 & 1 \\
\hline December Year-end Dummy & & 0.918 & 0.275 & 0 & 1 \\
\hline New Auditor Engagement Dummy & & 0.045 & 0.207 & 0 & 1 \\
\hline
\end{tabular}

All monetary amounts have been deflated by the implied GDP Deflator Index $(1985=100)$ Source: University of Nottingham Insurance Centre, Accountancy Age

Our dependent variable is the natural logarithm of the annual audit fee (following Gist, 1992 and Maher et al, 1992) expressed in 1985 prices by discounting by the GDP implied deflator index. In the case of subsidiary companies, the fee relates to only that company's audit. In the case of consolidated groups, the fee relates to the group audit, although affiliated companies (such as Eagle Star and Allied Dunbar, which are both owned by BAT) are normally treated separately.

Our independent variables form six groups: (1) insurance company size and structure variables - life and general business net premium written income, total assets, number of subsidiaries, number of overseas subsidiaries, and the number of US subsidiaries; (2) ownership structure variables - company type, subsidiary status, overseas parentage, UK head office location; (3) business portfolio and performance variables - split between life and general insurance, specialist reinsurance, and general insurance underwriting result; 
(4) governance variables - shareholder ownership, the proportion of non-executive directors, and Chairman/CEO split; (5) auditor-specific variables - auditor size, insurance market share, location of auditor, timing of audit, and new auditor engagement, and (6) time-dependent dummy variables (for the years 1984 to 1990) to pick up additional year-toyear variations in the real audit fee.

Total premium income: The main size variable is the natural logarithm of net written premium income (long-term and general insurance business) deflated by the Implied GDP Deflator Index $(1985=100)$. Previous audit fee research has identified size and complexity variables as being significant determinants of audit fees. Size has typically been represented either by value of total assets [Simunic, 1980; Francis, 1984; Francis and Stokes, 1987] and/ or by total sales revenue [Haskins and Williams, 1988]. In the models which utilise longterm and general premiums as separate variables, the logarithm of $(1+$ Premium Income $)$ is used to overcome the problem of specialist life and/or general insurers.

Total assets divided by total premiums: Total assets is an alternative measure of company size. The ratio of total assets to total premium income gives an indication of the mix of business: higher values denote a preponderance of 'long-tailed' liabilities (for example, liability business in general insurance, and pensions business in a life company).

Number of subsidiaries: Many of the largest UK insurers were formed from the gradual merger of smaller companies, which are often retained as operating subsidiaries. Thus larger companies tend to have more subsidiaries.

US subsidiary dummy: The United States is an important overseas market for many UK insurers, which have frequently established US subsidiaries or acquired US companies. In addition to the extra work involved in auditing subsidiary companies, it is expected that US based subsidiaries may expose the auditor to the hazards of the US litigation system.

Company type: A key characteristic of the ownership type and external governance of insurance companies is whether they are owned by shareholders (that is, proprietary companies) or by their policyholders (mutuals). The mutual-proprietary split is captured by an indicator variable (mutual $=1$ ), and another dummy denotes whether or not the company is a subsidiary stock company (subsidiary $=1$ ).

Overseas parent: Figures published by the regulatory authorities show that 17 per cent of all licensed UK insurance companies have their head office outside the UK [DTI, 1991]. Further dummy variables indicate if the company has an overseas parent (overseas parent $=1$ ) or a head office location outside the UK (UK HO location =1).

Specialist reinsurer: A small number of companies are specialist reinsurers (which may transact both life and general reinsurance). An indicator variable is used to denote such specialists (reinsurance company $=1$ ).

Trading performance: The mix of company types (proprietary/mutual) and the coexistence of life and general business in the sample make it difficult to devise a universal measure of trading performance. The general insurance underwriting result as a percentage of total premiums was utilised: this will be zero for specialist life offices.

Governance: The mutual insurance dummy is the main external governance variable since it denotes an absence of shareholders and stockmarket and/or parental control. Internal governance variables include the percentage of non-executive directors, and a dummy 
variable indicating the separation of the roles of Chairman and Chief Executive Officer (separate $=1$ ). We recognise that, in the case of subsidiary companies, a non-executive director may be an executive of the parent rather than a true outside director, and this possibility is picked-up by an interaction term (non-executive percentage * subsidiary).

Auditor size: We measure auditor size by the logarithm of turnover (i. e. total UK fee income from all sources) of the insurer's auditor in 1985 prices. Figures reported in Accountancy Age indicate that large audit/accountancy firms rely less on audit fee income than do smaller firms (for whom audit work is often over $70 \%$ of turnover). Because we can identify all the audit firms involved in insurance company auditing, we do not need to utilise a dummy variable to indicate the very largest auditors (unlike many other studies, e.g. Simunic, 1980; Turpen, 1990; Gist, 1992; Brinn et al, 1992).

Auditor insurance market share: We observe that large audit firms do not necessarily have a large share of the insurance audit market, since some auditors specialise in the audit of insurance groups. For each client insurer, we compute the auditor's share of the total sample insurance audit fee in each of the eight sample years: this is a measure of the extent to which individual audit firms concentrate on insurance clients.

Location of auditor: The audit fee may depend on the location of the auditor office. We therefore include a dummy variable to indicate whether the team conducting the audit was based in London (London $=1$ ) according to the address recorded after the audit report in the client's Report \& Accounts.

Timing of audit: The work load involved in auditing the many clients with accounting year-end at the end of December may involve additional expense. We have adopted the suggestion of Palmrose, 1989 and included a dummy variable to indicate audit timing (December year-end $=1$ ).

New auditor engagement: Numerous studies have indicated that the audit fee will be lower in the year following the engagement of a new auditor because of the possibility of lowballing (for example, Ettredge and Greenberg, 1990; Schatzberg, 1990; and Turpen, 1990). We therefore include a dummy variable to indicate a new engagement (new $=1$ ) and observe from the sample that, in most new engagements, the insurer switches to a larger firm of auditors. In order to model the differential impact of internal and external governance on new engagement fees, we include interaction terms with the mutual dummy (external), and the proportion of non-executives and the $\mathrm{CEO} /$ Chairman dummy (internal).

\section{Model and results}

We estimate a reduced-form linear model with pooled coss-section time series data from 117 insurance groups over the eight years between 1984 and 1991, giving a total sample of 936 observations.

The estimation technique described in Kmenta, 1986 assumes cross-section heteroscedasticity and time-wise first-order autocorrelation. Thus the estimated coefficients are the same for all observations, the disturbance vector follows a first-order time-wise autoregressive process which is different for each insurer, the variance of the disturbance term is heteroscedastic (i.e. different for each insurer), and the disturbances for different insurers are contemporaneously uncorrelated (i.e. cross-sectional independence between insurers is assumed). Since the data is limited to eight years, the first-order autoregression parameters are estimated as a sample correlation coefficient between successive disturbance terms. 
Table 2:

Pooled cross-section / time series regressions of insurance company log (audit fee) in 1985 prices for 117 companies, 1984-1991

\begin{tabular}{|c|c|c|c|}
\hline & & Coefficient & tvalue \\
\hline log Total Premiums & & 0.431 & 34.98 \\
\hline log Auditor Turnover & & $0.281 \mathrm{E}-01$ & 2.98 \\
\hline Assets/Premiums & & $0.240 \mathrm{E}-01$ & 11.19 \\
\hline No. of Subsidiaries & & $0.297 \mathrm{E}-01$ & 12.95 \\
\hline General Underwriting Ratio & & $-0.204 \mathrm{E}-02$ & -6.26 \\
\hline Auditor Insurance Mkt Share & & $0.150 \mathrm{E}-02$ & 1.72 \\
\hline Governance Variables & & & \\
\hline$\%$ Non-Executive Directors & $* *$ & -0.197 E-02 & -2.26 \\
\hline$\%$ Non-Exec ${ }^{*}$ Subsidiary & $* *$ & $0.153 \mathrm{E}-02$ & 1.56 \\
\hline Mutual Dummy & $* *$ & -0.663 & -11.95 \\
\hline Separate CEO/Chairman Dummy & $* *$ & $0.529 \mathrm{E}-01$ & 2.40 \\
\hline Mutual* New Auditor & $* *$ & -0.910 E-01 & -1.59 \\
\hline$\%$ Non-Executive ${ }^{*}$ New Auditor & $* *$ & 0.182 E-02 & 1.82 \\
\hline Separate CEO/Chairman* New Auditor & $* *$ & -0.202 & -2.04 \\
\hline Dummy Variables & & & \\
\hline New Auditor Engagement Dummy & & 0.287 E-01 & 0.32 \\
\hline Reinsurance Dummy & & -0.850 E-01 & -1.58 \\
\hline Subsidiary Dummy & & -0.380 & -5.30 \\
\hline Overseas Parent Dummy & & $-0.568 \mathrm{E}-01$ & -1.57 \\
\hline US Subsidiary Dummy & & 0.115 & 3.06 \\
\hline London Auditor Dummy & & 0.733 E-01 & 1.75 \\
\hline UK HO Dummy & & -0.327 E-01 & -0.99 \\
\hline December Year-end Dummy & & 0.104 & 2.30 \\
\hline 1984 Dummy & & $-0.461 \mathrm{E}-01$ & -1.49 \\
\hline 1985 Dummy & & -0.382 E-01 & -1.32 \\
\hline 1986 Dummy & & -0.426 E-01 & -1.59 \\
\hline 1987 Dummy & & -0.157 E-01 & -0.64 \\
\hline 1988 Dummy & & 0.438 E-01 & 1.95 \\
\hline 1989 Dummy & & $0.113 \mathrm{E}-01$ & 0.61 \\
\hline 1990 Dummy & & $0.410 \mathrm{E}-01$ & 3.03 \\
\hline Constant & & -1.018 & -5.11 \\
\hline Degrees of Freedom & & 907 & \\
\hline $\mathrm{R}^{2}$ & & 0.9802 & \\
\hline Wald $x^{2}$ (Governance Variables **) & & $184.6(7 \mathrm{DoF})$ & \\
\hline
\end{tabular}

[Shazam Econometrics Computer Programm, version 7.0, 1993] 
Table 3:

Pooled cross-section / time series regressions of insurance company log (audit fee) in 1985 prices for 117 companies, 1984-1991

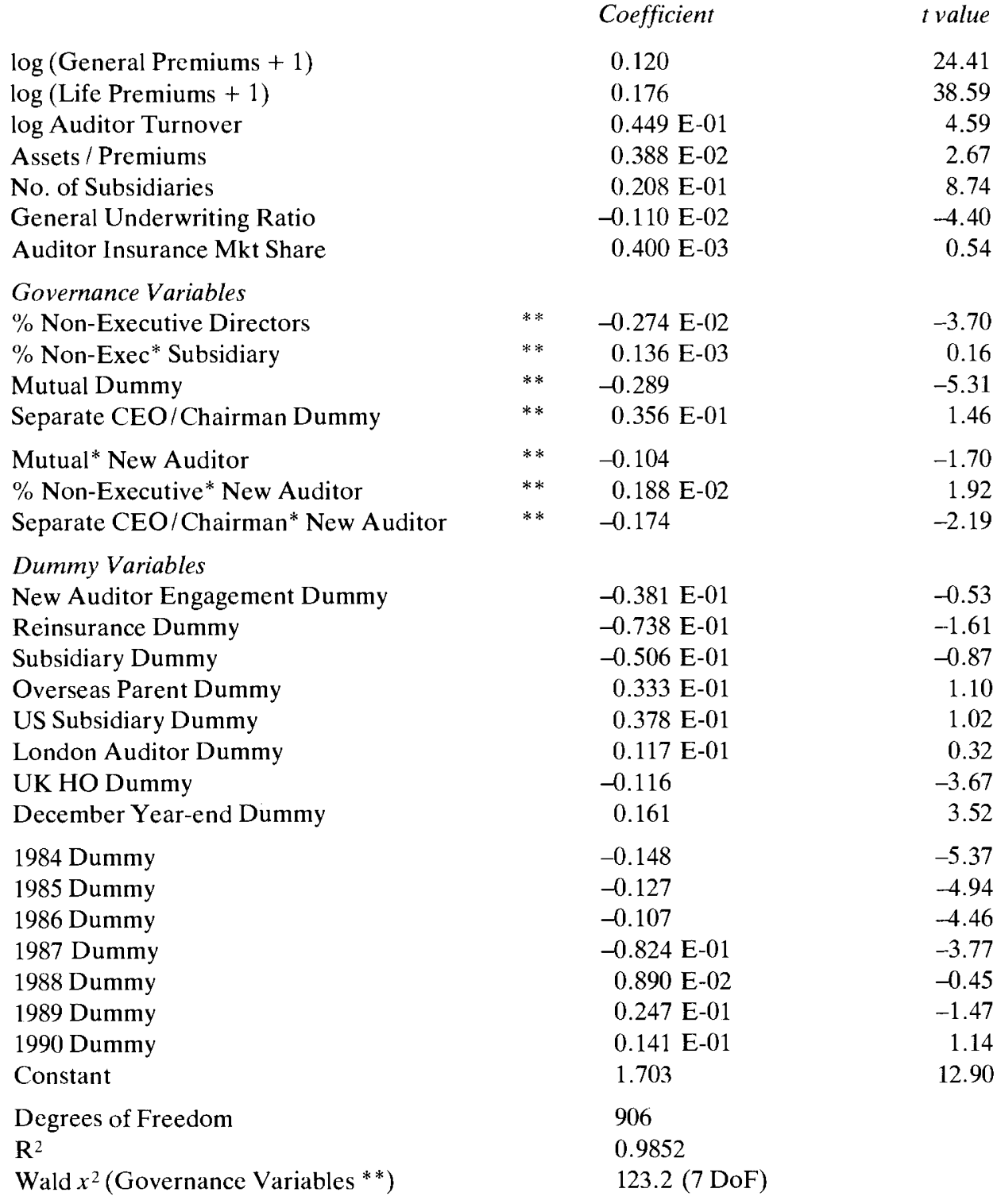

[Shazam Econometrics Computer Programm, version 7.0, 1993] 
Table 2 contains the results of the regression of the logarithm of insurance group audit fee on variables controlling for insurer size (measured by the logarithm of total premium income), ownership, performance, portfolio, and governance, and for auditor characteristics. Table 3 shows results from a similar estimation, but showing long-term and general insurance premiums separately. The $\mathrm{R}^{2}$ figures reported in the tables are computed as the square of the correlation coefficient between the actual and predicted values of the dependent variable (see Judge et al, $1985 \mathrm{ch} 2$ ). The Wald $x^{2}$ statistics show the result of variabledeletion tests on the governance variables (by testing linear restrictions on the coefficients indicated): in both Tables, the null hypothesis of zero coefficients is rejected resoundingly. Thus although there are obvious differences in the importance of the various governance variables, we find that the dependent variable is influenced significantly by the governance structure of UK insurance companies.

Tables 2 and 3 provide the following evidence on the behaviour of the logarithm of real audit fees of UK insurance companies:

\section{(1) Size of insurance group}

The coefficients of the logarithm of premium income are significantly positive in both models. The double-log formulation allows these coefficients to be interpreted as elasticities: a value less than unity implies that the audit fee increases at a lesser rate than premium income. The larger coefficient for life premiums in Table 3 shows that audit fees are more responsive to an increase in long-term premiums than to growth in general insurance business. Other measures of size such as the number of subsidiaries also have a significantly positive effect on audit fee.

\section{(2) Business portfolio and performance}

Not surprising, the structure and performance of the insurer's business portfolio has a strong influence on the dependent variable. The significant negative coefficient of the reinsurance dummy shows that, ceteris paribus, specialist reinsurance companies have a lower audit fee. Companies operating with subsidiaries in the USA appear to pay higher audit fees, although the US Subsidiary Dummy is only significant in Table 2.

The positive coefficient for the variable Assets/Premiums implies that insurance companies with a greater percentage of 'long-tailed' business are likely to be charged higher audit fees, perhaps because of the problems involved in estimating and auditing the appropriate level of technical reserves.

As expected, deteriorating general insurance underwriting results serve to increase the audit fee. Poor underwriting performance involves additional work and extra risk for auditors. As an illustration, the audit fee for the ninth largest UK general insurer, Municipal Mutual Insurance Company, increased sharply by 300 per cent in 1991 as poor underwriting performance pushed its statutory solvency margin below the acceptable minimum.

\section{(3) Ownership structure}

The effect of ownership on audit fees is ambiguous. Overseas parentage has no significant impact in either model, but the fact that an insurer is a subsidiary appears to reduce the audit fee (although the coefficient is only significant in Table 2). There is therefore some tenuous evidence that insurers which are subsidiary companies are charged a smaller fee (in contradiction to research reported by Brinn et al, 1992 in relation to companies in the electrical and electronic industry). 


\section{(4) Corporate governance structure}

In both models, the mutual status of insurance groups affects the audit fee via the mutual dummy and the interaction term with the new engagement dummy. The negative impact of the mutual dummy is quite marked and indicates that auditors reward mutuality with a lower audit fee - possibly because of the lower risk of discovery of audit error. The negative interaction term shows that mutual companies pay an even lower fee on new engagements in comparison with stock companies. This result implies that stock companies (with stronger external governance) are more likely than mutuals to pay lower 'renewal' audit fees, which supports our hypothesis that auditors may be more concerned to retain the renewal of the audit contracts of stock insurance companies.

Turning to the internal governance measures, Tables 2 and 3 both show that an increase in the percentage of non-executive directors will significantly reduce the audit fee. The positive coefficents for the interaction term with the subsidiary dummy indicate that nonexecutives are less effective in reducing the fee for subsidiaries, although these interaction variables are not strongly significant. Both models report a positive effect for the interaction term "\% Non-Executive *New Auditor", thus non-executive directors appear to be more effective at reducing renewal as opposed to initial audit fees.

The impact on the audit fee of the separation of Chairman and Chief Executive is particularly interesting. In both models, the coefficient of the dummy is positive (implying a higher fee with separation), but this is outweighed by a much larger significantly negative coefficient for the interaction term "Separate CEO/Chairman*New Auditor". In other words, CEO/Chairman separation serves to reduce new engagement audit fees, but increase renewal fees.

\section{(5) Auditor characteristics}

Auditors with a large turnover appear to charge higher audit fees. Similarly auditors with a large share of the insurance company audit market, and those based in London, are also associated with higher fees although the coefficients are not strongly significant. However both models provide significant evidence that insurers with a December year-end have to pay larger audit fees.

\section{(6) Time trends}

Finally the year dummies for the years 1984 to 1990 show that, in comparison with 1991 , most earlier years were associated with lower average real audit fees. The only exception is 1990 , which seems to have been a year of significantly higher fees on average.

\section{Conclusions}

This paper introduces a number of new issues in the discussion of the determinants of audit fees, by focusing on the importance of a company's governance and applying this focus to an industry, such as the UK insurance industry, where companies display a variety of different governance structures. We identify two main types of governance mechanisms. The main method of external governance is the exposure of proprietary companies to the market for corporate control: this exposure is lacking in mutual insurers which are owned by their policyholders. Internal governance mechanisms include the separation of the roles of chairman and chief executive and the existence of a high proportion of non-executive board directors. Internal and external governance affects both the probability of the issurance of incorrect financial statement, and their risk of discovery. 
Of all the governance variables that auditors may take into account in assessing audit fees, the mutual form of many of the largest UK insurers is the most important. Our econometric analysis indicates that, ceteris paribus, mutual insurers pay smaller audit fees than do stock or proprietary companies. This suggests that auditors are less worried about the absence of corporate control inherent in mutual companies, and regard mutuals either as less likely to issue unreliable financial statements or as a lower risk that auditor negligence will be detected.

Internal governance variables such as the separation of the roles of $\mathrm{CEO}$ and Chairman, and the percentage of non-executive directors also have a significant impact on audit fees. These governance variables appear to differ in their effect depending on whether the fee is associated with an initial engagement or the renewal of an existing contract. In general we find that strong internal governance and weak external governance are likely to reduce the audit fee paid, particularly on new engagements.

We suggest that future empirical research into the determinants of audit fee needs to incorporate governance structures in greater detail, taking care to distinguish their differential effects on initial engagement and renewal audit fees. Further research should also investigate the role of truly-independent non-executive directors, the importance of internal audit and remuneration committees, and organisational structure along the lines suggested by Ingham (1991).

\section{REFERENCES}

ANTLE, R. [1982] The Auditor as an Economic Agent, Journal of Accounting Research, Vol. 20, No 2, 503-527.

BAIMAN, S., EVANS, J.H. and NOEL, J. [1987] Optimal Contracts with a Utility-Maximising Auditor, Journal of Accounting Research, Vol. 25, No. 2, 217-244.

BRICKLEY, J.A. and JAMES, C.M. [1987] The Takeover Market, Corporate Board Composition, and Ownership Structure: The Case of Banking, Journal of Law and Economics, Vol. XXX, No. 1, $161-180$

BRINN, T., PEEL, M.J. and ROBERTS, R. [1992] Audit Fee Determinants of Independent and Subsidiary Unquoted Companies in the UK: An Exploratory Study, Discussion Papers in Accounting and Finance (92-103), Cardiff Business School, 1992.

Committee on the Financial Aspects of Corporate Governance, London, GEC, 1992.

De ANGELO, L.A. [1988] Managerial Competition, Information Costs, and Corporate Governance, Journal of Accounting and Economics, Vol. 10, 3-36.

Department of Trade and Industry [1991] Insurance Business Monitor.

DIACON, S. R. [1991] A Guide to Insurance Management, MacMillan Publishing, London.

DIACON, S. R. and O'SULLIVAN, N. [1993] Highballing and Lowballing in Audit Pricing: The Impact of Auditor Negligence, Unpublished Manuscript, School of Management \& Finance, University of Nottingham. 
ETTREDGE, M. and GREENBERG, R. [1990] Determinants of Fee Cutting on Initial Audit Engagements, Journal of Accounting Research, Vol. 28, No. 1, 198-210.

FIELDS, J. A. [1988] Expense Preference Behaviour in Mutual Life Insurers, Journal of Financial Services Research, Vol. 1, II3-129.

FIELDS, J.A. and TIRTIROGLU, D. [199I] Agency-theory Implications for the Insurance Industry: A Review of the Theoretical and Empirical Research, Quarterly Journal of Business and Economics, Vol. 30, No. I, 40-61.

FINANCIAL TIMES [1992] 'Writ issued against $\mathrm{BCCl}$ auditor' 13th March, p. 7.

FINANCIAL TIMES [1993] 'GRE issues writ against Coopers \& Lybrand' 4th January, p. 29.

FIRTH, M. [1985] An Analysis of Audit Fees and Their Determinants in New Zealand, Auditing: A Journal of Practice and Theory, Vol. 4, No. 2, 23-37.

FRANCIS, J.R. and STOKES, D. J. [1986] Audit Prices, Product Differentiation, and Scale Economies: Further Evidence from the Australian Market, Journal of Accounting Research, (Autumn), VoI. 24, No. 2, 283-393.

FRANCIS, J. R. and SIMON, D. T. [1987] A Test of Audit Pricing in the Small-Client Segment of the U.S. Audit Market, The Accounting Review, (January), Vol. LXII, No. 1, I45- I57.

GIST, W. E. [1992] Explaining Variability in External Audit Fees, Accounting and Business Research, Vol. 23, No. 89, 79-84.

GODSELL, D. [1991] Auditors' Legal Duties and Liabilities, London, Longman.

HASKINS, M.E. and WILliAMS, D.D. [1988] The Association Between Client Factors and Audit Fees: a Comparison by Country and by Firm, Accounting and Business Research, Vol. 18, No. 70, $183-190$.

INGHAM, H. [1992] Organisational Structure and the Internal Economy of the Firm: the UK Insurance Industry, Managerial and Decision Economics, Nov./Dec, 463-474.

JENSEN, M.C. and MECKLING, W.H. [1976] Theory of the Firm: Managerial Behaviour, Agency Costs and Ownership Structure, Journal of Financial Economics, Vol. 3, 305-360.

JUDGE, G., GRIFFITHS, W., HILL, R., LUTKEPOHL H. and LEE, T. [1985] The Theory and Practice of Econometrics, Wiley, 2nd ed.

KAPLAN, S. N. [1985] An Examination of the Effects of Environment and Explicit Internal Control on Planned Audit Hours, Auditing: A Journal of Practice and Theory, Fall 12-25.

KAPLAN, S. N. and REISHUS, D. [1990] Outside Directorships and Corporate Performance, Journal of Financial Economics, Vol. 27, 389-4I0.

KMENTA, J. [1986] Elements of Econometrics, MacMillan, 2nd cd.

LAMM-TENNANT, J. and STARKS, L. T. [1993] Stock versus Mutual Ownership Structures: The Risk Implications, Journal of Business, Vol. 66, No. I, 29-46.

LOW, LAY-CHIN, TAN PEARL HOCK-NEO and KOH H.C. [1989] The Determination of Audit Fces: An Analysis in the Singapore Context, Journal of Business Finance and Accounting, Vol. 17, No. 2, 285-295.

MAHER, M.W., TIESSEN, P., COLSON, R. and BROMAN, A. J. [1992] Competition and Audit Fees, The Accounting Review, Vol. 67, No. I, 199-21I.

MAYERS, D. and SMITH, C. W. [1992] Executivc Compensation in the Life Insurance Industry, Journal of Business, Vol. 65, No. I, 5I - 74.

MELUMAD, N. and THOMAN, L. [1990a] On Auditors and thc Courts in an Adverse Selection Setting, Journal of Accounting Research, Vol. 28, No. 1, 77- I20. 
MELUMAD, N. and THOMAN, L. [1990b] An Equilibrium Analysis of Optimal Audit Contracts, Contemporary Accounting Research, Vol. 7, No. 1, 22-55.

O'HARA, M. [1981] Property Rights and the Financial Firm, Journal of Law and Economics, Vol. XXIV, 317-332.

O'SULLIVAN, N. [1993] Auditors' Liability: Its Role in the Corporate Governance Debate, Accounting and Business Research, Vol. 23, No. 91 A, 412 - 420.

PALMROSE, Z.V. [1986] Audit Fees and Auditor Size: Further Evidence, Journal of Accounting Research, Vol. 24, No. 1, 97-111.

PALMROSE, Z. V. [1988] An Analysis of Auditor Litigation and Audit Service Quality, The Accounting Review, Vol. LXIII, No. 1, 55-73.

PETRONI, K. R. [1992] Optimistic Reporting in the Property-Casualty Insurance Industry, Journal of Accounting and Economics, Vol. 15, No. 4, 485-508.

ROSENSTEIN, S. and WYATT, J. G. [1990] Outside Directors, Board Independence, and Shareholder Wealth, Journal of Financial Economics, Vol. 27, 175-191.

SCHATZBERG, J.W. [1990] A Laboratory Market Investigation of Low Balling in Audit Pricing, The Accounting Review, Vol. 65, No. 2, 337-362.

SIMON, D. T. [1985] The Audit Services Market: Additional Empirical Evidence, Auditing: A Journal of Practice and Theory, Vol. 5, No. 1, 71-78.

SIMUNIC, D. A. [1980] The Pricing of Audit Services: Theory and Evidence, Journal of Accounting Research, Vol. 18, No. 1, 161-190.

ST. PIERRE, K. and ANDERSON, J. A. [1984] An Analysis of the Factors Associated with Lawsuits Against Public Accountants, The Accounting Review, Vol. LIX, No. 2, 242-263.

SMITH, B.D. and STUTZER, M. J. [1990] Adverse Selection, Aggregate Uncertainty, and the Role for Mutual Insurance Contracts, Journal of Business, Vol. 63, No. 4, 493-511.

THORNTON, D.B. and MOORE, G. [1993] Auditor Choice and Audit Fee Determinants, Journal of Business Finance and Accounting, Vol. 20, No. 3, 333-349.

TURPEN, R.A. [1990] Differential Pricing on Auditors' Initial Engagements: Further Evidence, Auditing: A Journal of Practice and Theory, Vol. 9, No. 2, 60-76.

WALLIN, D. E. [1992] Legal Recourse and the Demand for Auditing, The Accounting Review, Vol. 67 , No. 1, $121-147$.

WALSH, J.P. and SEWARD, J. K. [1990] On the Efficiency of Internal and External Corporate Control Mechanisms, Academy of Management Review, Vol. 15, No. 3, 421-458.

WEISBACH, M.S. [1988] Outside Directors and CEO Turnover, Journal of Financial Economics, Vol. 20, 431-460. 